dr. Ana Krajnc profesorica na Filozofski fakulteti in vodja katedre za andragogiko

\begin{abstract}
A tos že tretje leto. Metodično je bila že od začetka posebno oblikovana. Pomemben del aktivnega učenja udeležencev je prenesen na neposredno interakcijo s predstavniki kraja (lokalnimi koordinatorji), delavnice in medsebojne razprave ter neformalno druženje ves čas skupnega bivanja. Didaktično in vsebinsko je domišljena celota namenjena strokovnjakom za izobraževanje odraslih in drugim, ki jih zanima sodobno učenje, razvoj ljudi in kraja. Občina Ajdovščina je eksperimentalno zaledje, zato je zelo pomembno stalno sodelovanje $\mathrm{z}$ lokalnimi koordinatorji skozi vse leto, med pripravami na andragoško poletno šolo.
\end{abstract}

\section{OSNOVNI PRISTOP}

Udeleženci se na podlagi študija primera pripravljajo za neposredno izobraževalno delovanje v svojih občinah. Enotedensko srečanje združuje priznane tuje in domače teoretike ter praktike. Med udeleženci je zelo močan mo-

Osredni namen andragoške poletne sole kot oblike nadaljujega izobraževanja in druženja andragegov je pospeševanje razvoja andragoske prakse in teorije, spodbujanje k novim raziskavam in povezovanje s tujimi najpomembnejšmi inštituti in strokovnjaki za vzgojo in izobraževanje odraslih.

tiv, to je spoznavanje novih znanstvenih dognanj $\mathrm{v}$ andragogiki in pri uvajanju novosti $\mathrm{v}$ andragoško prakso pri nas.

Razprave in delavnice povezujejo uvodna teoretična predavanja. Kulturna dejavnost kraja je eden najbolj pomembnih dejavnikov za prebujanje in razvoj človeških zmožnosti.
Prirojene dispozicije se razvijajo, če je človek dejaven in ima priložnost, da se vključuje $\mathrm{v}$ dogajanje. Zato je $\mathrm{v}$ andragoški poletni šoli vsakodnevni kulturni program še posebno pomemben. Vsak dan se konča s kulturno prireditvijo. Poleg andragogov se prireditve udeležijo tudi domačini (lokalni koordinatorji, sodelavci, zainteresirani občani, vodje študijskih krožkov in drugi). Enotedensko skupno bivanje daje zadosti priložnosti tudi za neformalno druženje med udeleženci. Stike navežejo tudi z lokalnimi koordinatorji in pomembnimi osebnostmi iz okolja. Medsebojne interakcije so večplastne in naglo pospešujejo medsebojno učenje.

\section{OBČINA AJDOVŠČINA KOT POSKUSNO ZALEDJE IN MODEL}

Tako ustvarja andragoška poletna šola tudi trajnejše vezi, sodelovanje se nadaljuje tudi med letom, porajajo se spontane želje, da bi se pogosteje srečevali vsaj $\mathrm{v}$ manjših skupinah. Nastaja medsebojna pripadnost. Občutek pripadnosti obarva sodelovanje $\mathrm{z}$ nekakšno klubsko mentaliteto. Formalni odnosi preidejo $\mathrm{v}$ neformalne, iz kolegialnih odnosov se oblikujejo tudi prijateljske vezi.

Poleg vsebinskega je bil že na začetku izoblikovan tudi didaktični model andragoške poletne šole. Beseda »šola « je uporabljena predvsem $\mathrm{v}$ figurativnem pomenu besede. Skupina, ki jo je uvedla, je želela ustvariti tako obliko izobraževanja, ki bi pomenila nasprotje formalnemu šolskemu delu. Zato so se zbrani andragogi glede učne metode osredotočili na metode »interakcijskega izobraževa- 


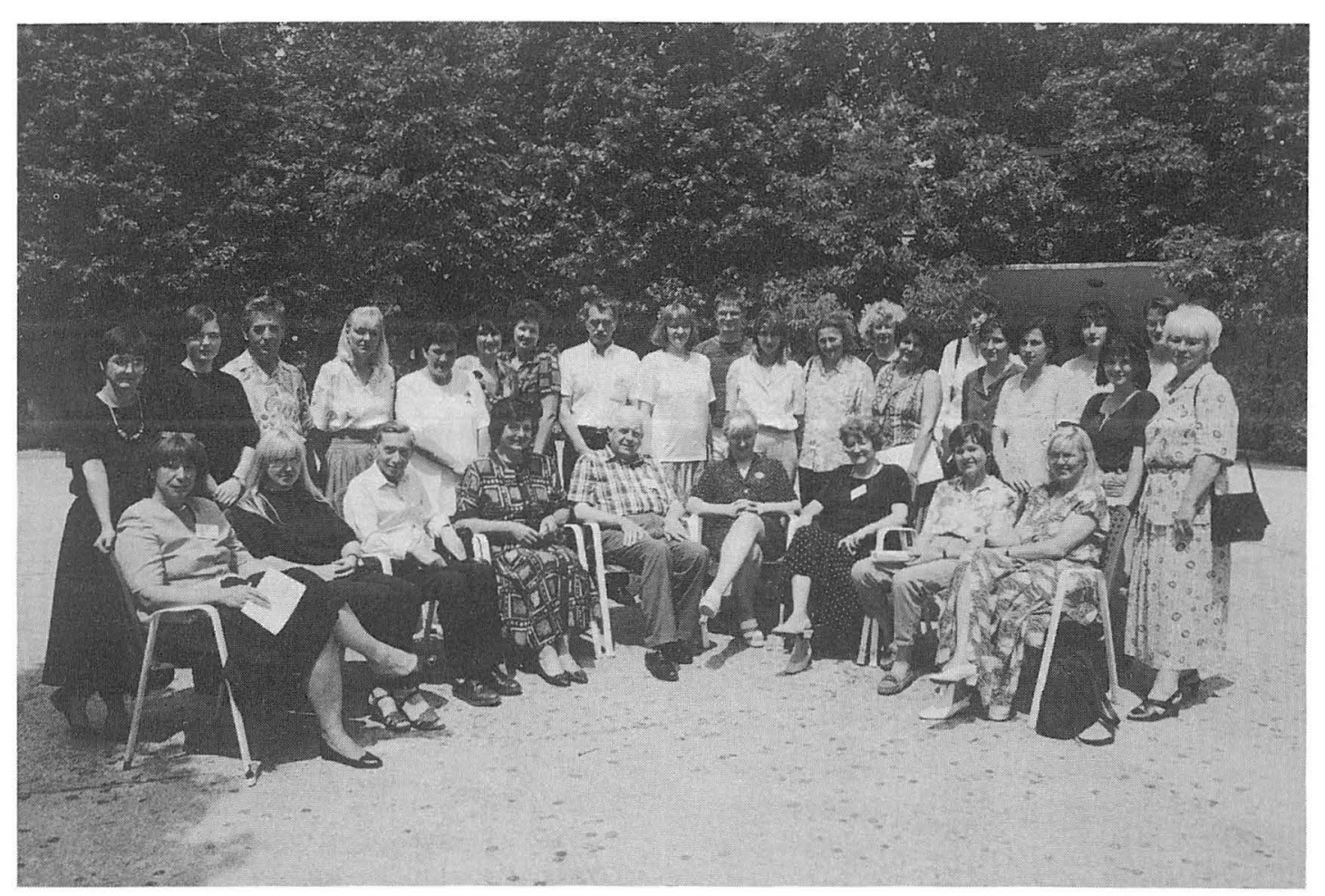

nja «, na dialog in na neposredno okolje, kjer andragoška poletna šola poteka.

Dopolnilno izobraževanje andragogov je $\mathrm{v}$ andragoški poletni šoli zastavljeno tako, da vsebuje veliko neposrednih praktičnih oblik aktivnosti in ustvarjanje udeležencev na samem kraju dogajanja. Zato potrebujejo ustrezno bazo podatkov, možnost opazovanja konkretnih primerov za analize in praktične okoliščine, kjer bi lahko svoje izdelke preizkušali. Nastanek šole je zato že od začetka tesno povezan s sodelovanjem $\mathrm{z}$ lokalnimi strokovnjaki in ljudmi iz Ajdovščine. Tako so udeleženci neposredno na terenu, $\mathrm{z}$ obiski na domu in $\mathrm{v}$ javnih lokalih ugotavljali potrebe po znanju in probleme mladih $\mathrm{v}$ kraju, starejših in brezposelnih. Na podlagi individualnih zgodb so prepoznali značilne probleme posamezne socialne skupine. Pokazale so se zelo različne potrebe po znanju, stališča in vrednote. Samo kot take se lahko uporabljajo $\mathrm{v}$ zvezi z izobraževanjem $\mathrm{v}$ kraju, namenjenem reševanju problemov ljudi in razvoju občine.

Andragoške poletne šole tudi ni mogoče seliti iz kraja v kraj, ker je treba postopno razviti medsebojna razmerja in podrobno spoznati posebnosti kraja in ljudi ter objektivnih razmer. Celotna dejavnost je nekakšna generalka za to, kar bodo udeleženci pozneje počeli na matični andragoški ustanovi.

\section{VSAKOLETNE PRIPRAVE IN OSNOVNA ORGANIZACIJA}

Priprave se začnejo vsako jesen $\mathrm{v}$ prejšnjem letu. Domačinom v občini najprej predstavimo izdelke udeležencev, na primer fotodokumentacijo o javnih komunikacijah v kraju, predlog programa za delo $\mathrm{z}$ mladimi, lepake in priprave za radijske oddaje s temo tretje življenjsko obdobje «, poročilo o intervjujih s funkcionalno nepismenimi občani, predlogi za študijske krožke in nove oblike izobraževanja odraslih.

$\mathrm{Na}$ osnovi razgovorov se lokalni koordinatorji in predstavniki občine odločijo, katere izmed »izdelkov « bodo prevzeli in jih uresničili v praksi. Vodje andragoške poletne šole se pri tem še podrobneje seznanijo $\mathrm{z}$ razlogi proti takim izobraževalnim programom in za njih. Predstavniki andragoške poletne šole se udeležijo odprtja univerze za tretje življenjsko obdobje, okrogle mize $\mathrm{z}$ aktualno temo o znanju in prihodnosti in navežejo stik z morebitnimi mentorji za lokalne študijske krožke.

Začno se okvirni pogovori in priprave na naslednjo andragoško poletno šolo. Vodje andragoške poletne šole zbirajo različno gradivo, poročila o delu društev, podatke o ekonomskem in socialnem načrtovanju, sprotnih dejavnostih in informacije o pomembnejših dogodkih v kraju. Čim preglednejša slika na-
Udeleženci

Andragoške poletne šole $v$ Ajdoušcini 
stane na osnovi gradiva, tem laže se odločijo, kaj ustreza temi naslednje andragoške poletne šole (letos je na vrsti strategija programiranja izobraževanja odraslih za razvoj ljudi in kraja).

Večino zbranega gradiva imajo udeleženci na voljo med potekom šole. Uporabljajo jih zlasti $\mathrm{v}$ delavnicah in pri aktivnem izobraževanju, ko sami pripravljajo poskusne predloge programov. Tam, kjer lahko zagotovijo ustrezno število kopij, dobi vsak udeleženec svoj izvod.

Med pripravami je treba pripraviti tudi lokalne koordinatorje, ki bodo neposredno sodelovali v razpravah na andragoški poletni šoli $\mathrm{v}$ juniju. Tako povečamo možnosti, ki jih imajo udeleženci na voljo za spoznavanje in učenje. V priprave je vključenega veliko sistematičnega dela in zavestnega prizadevanja, kajti tudi dopolnilno izobraževanje strokovnjakov mora biti skrbno strukturiran in ciljno

Potrebe po znanju naraščajo in se selijo iz tovarn na lokalno raven, torej tja, kjer so liudje in njihovi problemi. naravnan proces, če hočemo, da bo andragoška poletna šola dosegla predvidene cilje.

Pri organizacijskih pripravah je pomembno spoznati, kaj nam lahko kraj v zvezi s andragoško prakso ponudi. $Z$ opazovanjem je treba izluščiti tiste najdragocenejše vzgibe kulturnega in socialnega življenja kraja, za katere mislimo, da bodo pomembno vplivali na usposabljanje strokovnjakov tudi drugje $\mathrm{v}$ Sloveniji.

Med priprave, ki jih izvajamo med letom, spadajo tudi videoposnetki. Te $z$ ustrezno interpretacijo predstavimo udeležencem andragoške poletne šole. Tako smo prvo leto predstavili dva videoposnetka kot primera izredno uspešnega izkustvenega učenja dveh moških iz ajdovske občine. Naredili smo še več videoposnetkov z ljudmi, za katere je značilno izrazito samostojno učenje in osebnostni razvoj tudi v srednji življenjski starosti. Letos smo pripravili videoposnetke o andragoški poletni šoli kot primeru interakcijskega izobraževanja za lokalni razvoj, s katerim se naj bi na Unescovi svetovni konferenci v Hamburgu (julija 1997) poleg štirih drugih držav predstavila tudi Slovenija in izobraževanje za lokalni razvoj. V Montrealu smo s sodelavci Unescovega projekta ALPHA Izobraževanje in lokalni razvoj februarja 1997 posneli video- prispevek o strokovnih izhodiščih. Oba prispevka bosta skupaj s francoskim in češkim videom predstavljena na andragoški poletni šoli (prav tako pripravljena za Unesco), ki so nam ju dali na voljo.

$\mathrm{Na}$ šoli naj bi predstavili domače in tuje pomembne strokovne dosežke in tako pospešili razvoj andragoške prakse pri nas. Poleg domačih strokovnjakov vsako leto sodeluje tudi kateri izmed mednarodno priznanih strokovnjakov za izobraževanje odraslih, ki so po svojih raziskavah in objavah najbližje obravnavani temi.

\section{INTERAKCIJSKO IZOBRAŽEVANJE KOT OSNOVA ZA DOPOLNILNO USPOSABLJANJE STROKOVNJAKOV ZA IZOBRAŽEVANJE ODRASLIH}

Učenje na andragoški poletni šoli večinoma poteka na osnovi osebnih stikov in medosebnih odnosov oziroma interakcij med ljudmi. Nova spoznanja črpajo udeleženci tudi iz dialogov, opazovanja in vtisov, iz pripovedovanja drugih o sebi. Pomen lokalnega radia za razvoj izobraževanja odraslih presojajo na podlagi neposrednih izkušenj, tako da skupina nastopi na ajdovskem radiu Nova. K sodelovanju je povabljena tudi televizija Primorka in goriško predstavništvo Televizije Slovenija. Izkušnje za delovanje $\mathrm{v}$ lastni občini pridobivajo tudi tako, da pripravljajo prispevke za tisk in iščejo stike $\mathrm{z}$ novinarji. Interakcijsko

Interakcijsko izobraževanje onogoča, da se izrazita oba sogovornika ali več sodelujočih oseb, osebe $v$ vlogi učenca in oseba $v$ vlogi učitelja. Kaj je pravo znanje ob pravem času in na pravem kraju, določata oba. Zato ne sme odnos temeljiti samo na učitelju, ki je odgovoren za izobraževanje.

izobraževanje je aktivno učenje. Poteka sredi življenja in na podlagi stikov z ljudmi na dejanskih položajih.

Vsako učenje je spoznavanje novega, je pot $\mathrm{v}$ neznano. Če gre učenec predaleč, ker ne upošteva sogovornika, obstaja nevarnost, da bo napravil napako. Zato ne sme izhajati samo iz sebe. Spoznati mora in upoštevati sogovornika. Kakšen bo pravi odgovor na potrebe ali kakšno pravo znanje, je odvisno od obeh. Soočenje obeh, učitelja in učenca, interakcija 
med obema pokaže pravo potrebo po znanju, nadzoruje učne rezultate in daje uporabno in "živo" znanje. Andragogi morajo biti za uspešno izobraževanje za razvoj kraja in ljudi v nenehnem stiku z okoljem in ljudmi.

Interakcije so večplastne. Stik in dialog z ljud$\mathrm{mi}$ dopolnjujejo interakcije $\mathrm{z}$ drugimi strokovnjaki (gostujoči znanstveniki) in kolegi s podobnih ustanov, kot so ustanove, s katerih sami prihajajo (s strokovnjaki za izobraževanje odraslih). Zato pravimo, da poteka interakcijsko izobraževanje po večplastnih izmenjavah in stikih. Andragog naj bi bil dovzeten za razne namige, vtise in opazovanja, sprejemljiv za komunikacijo z vsemi ljudmi.

Načrtovanje in programiranje izobraževanja ni niti stvar posameznika niti ne more biti odgovornost posameznega strokovnjaka, ker je nevarnost, da napravi napako, ko zastavlja

Izobraževanje odraslih se naj bi po svoji naravi in osnovnih kvalitetah andragoškega procesa vključevalo $v$ dejanske razmere in življenje, naravnano na življenjske potrebe in probleme, prirejeno za določene okolišexine, določeno skupino ljudi ali določen kraj.

izobraževalne programe, prevelika. Splet okoliščin ali življenje samo določajo, katero znanje ljudje najbolj potrebujejo.

Seminar, zasnovan na metodi interakcijskega izobraževanja, ne more potekati brez sodelovanja ljudi iz prakse in predstavnikov ciljnih skupin. Zato je potrebnega veliko dogovarjanja v kraju, kjer andragoška poletna šola poteka. To zahteva od snovalcev precejšnje poznavanje lokalnih razmer in socialnih struktur. Nekatere stvari je mogoče uresničiti prek lokalnih institucij, zelo pa je pomembno tudi neformalno sodelovanje in druženje $z$ ljudmi v kraju. Neformalni stiki z ljudmi v kraju so bili zlasti $\mathrm{v}$ ospredju pri pripravah na prvo andragoško poletno šolo in pri prvih stikih $\mathrm{s}$ krajem.

\section{STRUKTURA ANDRAGOŠKE POLETNE ŠOLE IN NEKATERA NEREŠENA VPRAŠANJA}

V interakcijskem izobraževanju se prepletata teorija in praktične vaje. Sam način dela dolo- ča izvajalcem določene naloge, in sicer, da zagotovijo opazovanje praktičnih primerov, ustvarjalni dialog in odpravljanje dilem pri odločanju o izobraževalnih programih, medsebojno izmenjavo in povezovanje izkušenj vseh udeležencev in razvijajo izobraževanje kot skupno odgovornost vseh sodelujočih. To, koliko nekdo dobi od seminarja ali konference, je odvisno predvsem od njega samega, od tega, kaj sprašuje, v kakšnih dialogih sodeluje, kaj opazuje, do katere stopnje preizkuša realnost, za katere teoretične poglede se odloči itd. Bojmo se ljudi, ki brezbrižno zatrjujejo, kako je konferenca zanič in $\mathrm{z}$ njo niso nič pridobili. Noben seminar ne more biti tako slab, da udeleženec, ki je sodeloval $\mathrm{z}$ vso svojo radovednostjo in sposobnostmi, ne bi ničesar pridobil. Odmaknjen in pasiven udeleženec pa tudi z najboljših konferenc ne odnese kaj dosti.

Andragoška poletna šola poteka $\mathrm{v}$ treh delih: - dopoldanski plenarni del, predavanja, razprave in predstavitve literature, razstave;

- popoldansko "delo na terenu ", udeleženci se razidejo po različnih ustanovah, po domovih ljudi, opazujejo $\mathrm{v}$ javnosti in navezujejo stike $\mathrm{z}$ ustanovami;

- kulturni del ob večerih pripomore $k$ sproščenosti, izmenjavi dnevnih vtisov in izkušenj, zbliževanju sodelujočih $\mathrm{z}$ domačini in $\mathrm{k}$ večji motivaciji.

Nič ne poteka po naključju ali kar tako, vsak dogodek ima svojo didaktično funkcijo. Vsak izmed naštetih delov enotedenskega interakcijskega izobraževanja, namenjenega izpopolnjevanju andragogov iz vse Slovenije, ima svojo posebno vlogo in je namenoma vgrajen v celoto. Popoldanski del programa temelji predvsem na izkustvenem učenju udeležencev. Osmišljajo ga plenarna predavanja in razprave. Tako se praksa na podlagi teorije in refleksije spreminja $\mathrm{v}$ izkustvo.

Že od vsega začetka se postavlja vprašanje: zakaj poteka andragoška poletna šola prav v Ajdovščini. Odgovor se glasi: namenoma. Raziskave nam ves čas kažejo veliko centraliziranost izobraženih ljudi (večina fakultetno izobraženih živi v Ljubljani), to velja tudi za izobraževanje odraslih, pa naj gre za ta ali 


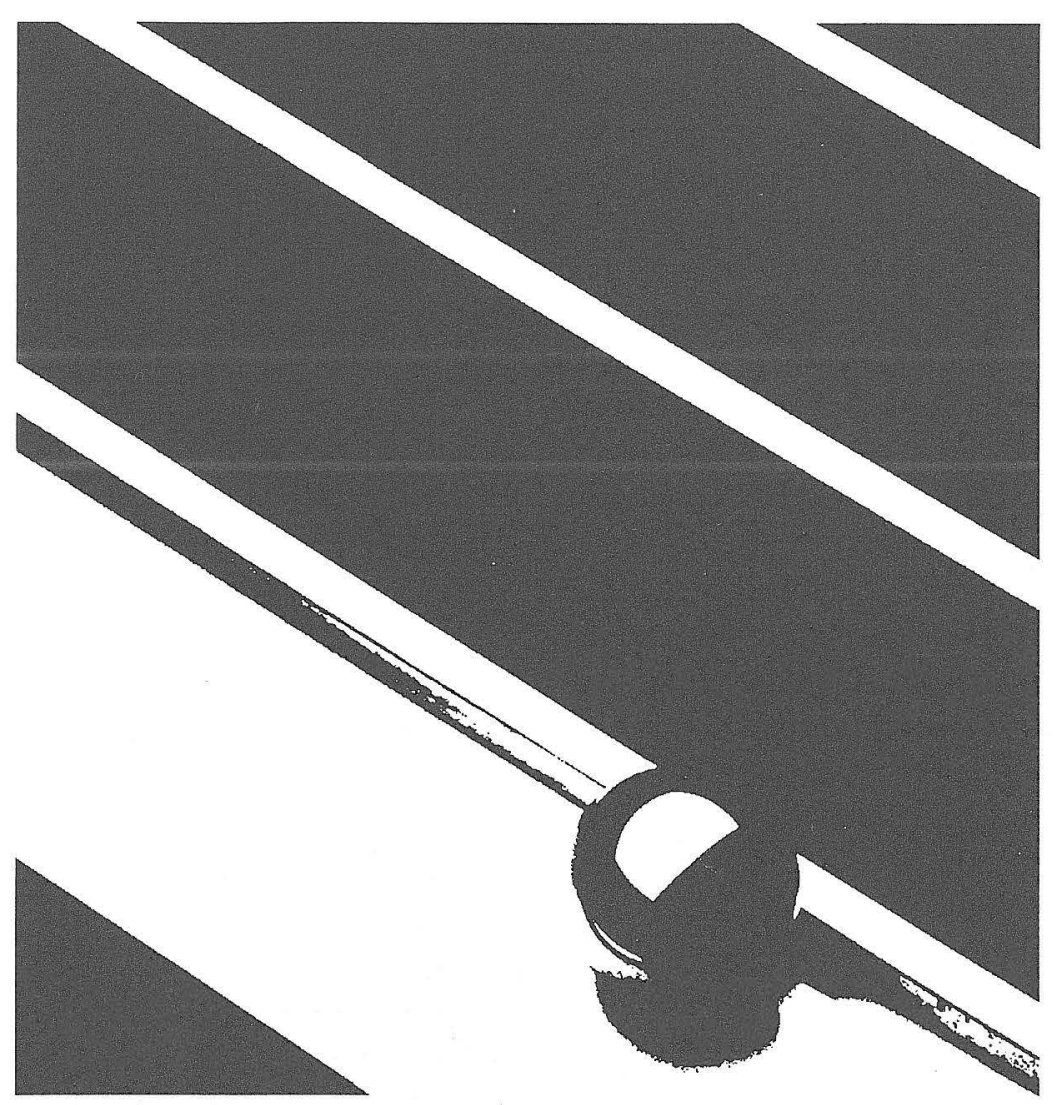

drugi andragoški pojav (večerne šole, izredne študente, študijske krožke, programe za funkcionalno pismenost itd.). Preprečevati nekomu izobraževanje pomeni enako, kot bi človeku odvzeli kisik, brez dihanja ne more živeti. Znanje je danes osnova preživetja ljudi. Zato naj bi bila posebna skrb države in občine posvečena prav temu, da bi bilo znanje dostopno vsakemu človeku. Andragoško poletno šolo smo namenoma locirali $\mathrm{v}$ manjšem kraju, oddaljenem od glavnega mesta, da bi tudi v Sloveniji pospešili decentralizacijo in demokratizacijo izobraževanja.

Namesto za Ajdovščino bi se lahko odločili tudi za kak drug manjši kraj v južnem delu Slovenije, ki po andragoških aktivnostih v primerjavi s Štajersko in Gorenjsko ter ljubljansko regijo zaostaja. Rezultate takega lociranja že čutimo. V občini Ajdovščina je več zanimanja za izobraževanje odraslih. Študij andragogike je vpisalo nadpovprečno število študentov iz tega kraja. $Z$ novimi programi na novoustanovljeni univerzi za tretje življenjsko obdobje, večjim številom zaposlenih na ljudski univerzi in nastajajočim klubom za mlade bodo tudi ljudje $\mathrm{v}$ kraju neposredno začutili nov utrip izobraževanja.

Pojavlja se tudi vprašanje, ali se bo andrago- ška poletna šola selila iz kraja v kraj. Po metodah, ki jih $\mathrm{v}$ zvezi s to obliko izpopolnjevanja strokovnjakov za izobraževanje odraslih uporabljamo, je to skoraj nemogoče. Priprave na interakcijsko izobraževanje zahtevajo veliko vnaprejšnjih priprav in dobro vraščenost $\mathrm{v}$ kraj. O kraju in ljudeh $v$ njem je treba vnaprej veliko vedeti. Znanje o tem se iz leta $\mathrm{v}$ leto dodaja in tako se povečuje tudi kvaliteta poletne šole. Če bi se APŠ selila iz kraja v kraj, bi ostajala kvalitetno vedno na enaki ravni oziroma na začetku poti ter priprav.

Tako pa se lahko udeleženci do podrobnosti seznanijo $\mathrm{z}$ razmerami $\mathrm{v}$ poskusni občini, spoznajo ljudi in prenašajo pridobljeno znanje $\mathrm{v}$ andragoško dejavnost $\mathrm{v}$ svoji občini. Prenos v domače razmere ni zahteven, ker se ljudje med seboj poznajo. $V$ domačem kraju lahko udeleženec načrtuje izobraževanje odraslih glede na potrebe ljudi še veliko podrobneje, kot je poskusno načrtoval na andragoški poletni šoli. Doma udeležencu nobena podrobnost ne uide. Zato je mnogo učinkovitejše prenašanje naučenega $\mathrm{v}$ nove razmere prek udeležencev v druge občine, kot pa to, da bi se šola selila iz kraja $\mathrm{v}$ kraj.

\section{ZNAČILNOSTI INTERAKCIJSKEGA IZOBRAŽEVAN】A}

$\mathrm{Za}$ interakcijsko izobraževanje je značilno poseganje $\mathrm{v}$ neposredno okolje in obojestranska aktivnost vodje izobraževanja oziroma mentorja in udeležencev seminarja. Pomemben del interakcijskega izobraževanja nastaja na podlagi stikov z okoljem. Namenoma izbrane osebe, ki v kraju kaj več vedo o potrebah ljudi in manjkajočih oblikah znanja ali pa so nosilci lokalnih pobud in spodbujevalci različnih projektov ter društev so bili izbrani že med pripravami na APŠ. Te osebe so bile najpomembnejši ljudje ali lokalni koordinatorji ter so skrbeli za druge stike, potrebne za študij med samo poletno šolo. Krog lokalnih koordinatorjev sestavlja približno petnajst ljudi, prek njih pa smo sodelovali tudi z drugimi občani. Udeleženci APŠ odkrivajo globlji pomen »na učenca naravnanega « izobraževanja odraslih.

Interakcijsko izobraževanje je prek lokalnih koordinatorjev prehajalo $\mathrm{v}$ stike $\mathrm{z}$ občani. Izobraževanje in študij v APŠ sta strnjena ter intenzivna oblika enotedenskega učenja. Inte- 
rakcijsko izobraževanje ne sestavljajo naključni ali občasni stiki, temveč je struktura izbranih primerov in zavestnih, namernih potez.

Lokalni koordinatorji so nam dali naslove občanov, ki bi bili primerni za pogovor o tem ali ki smo jih obravnavali v APŠ. Najprej so se z ljudmi, ki bi prišli v poštev, pogovorili. Če so privolili v sodelovanje, so nam dali naslov teh ljudi. Tako je nastal seznam prebivalcev Ajdovščine, s katerimi bodo med poletno šolo navezali stik in se pogovarjali o potrebah po znanju, problemih in položaju mlajših $\mathrm{v}$ občini, o starejših in upokojencih ter o problemih funkcionalno nepismenih ljudi, ki živijo na družbenem robu.

Vse tri izbrane skupine spadajo med prebivalstvo, ki je potisnjeno na rob, v zvezi z njimi smo že med pripravami na APŠ predvidevali, da je reševanje problemov in pridobivanje znanja najbolj pereče. Zato smo se že v vsebinskem delu zavestno odločili za tak izbor ljudi.

Med pripravami in tudi pozneje pri izvajanju interakcijskega izobraževanja je posebno izstopal problem funkcionalno nepismenih ljudi. Ker smo se v zvezi s tem primerom tudi sami učili in odkrivali nova razmerja $\mathrm{v}$ izobraževanju, ga bomo tudi posebej opisali.

Lokalni koordinatorji so se pritoževali, da niso uspešni pri pridobivanju imen in naslovov ljudi z najnižjo izobrazbo ali funkcionalno nepismenih oseb (tega strokovnega izraza nismo nikoli dobesedno uporabili). Skoraj nihče izmed vprašanih ni hotel privoliti $\mathrm{v}$ to, $\mathrm{da}$ bi se poleti $\mathrm{z}$ njim sestali in se pogovarjali. Koordinatorji so pri kasnejšem poskusu zožili krog spraševanja na svoje neposredne znance in poznane, s katerimi so tudi sicer $\mathrm{v}$ stikih, bodisi v službi, stanovanjski soseski ali pa so njihovi sorodniki. Toda tudi ta poskus ni bil uspešen. Vprašani so se plašno obdajali $z$ molkom in se niso bili pripravljeni pogovarjati z andragogi, seminaristi. Gledali so jih bolj kot podaljšek oblasti (to je bilo razumeti iz njihovih pripomb: potem bom moral še davke plačati, nočem imeti nobenih sitnosti $z$ uradi, jaz tako nič ne vem, drugi so za to, da govorijo, nimam kaj povedati, kdo me pa bi sploh poslušal itd.) in so jih zato že vnaprej odklanjali. Funkcionalno nepismeni gotovo ne želijo svoje osebne socialne nemoči razka- zovati drugim in se raje zapirajo $\mathrm{v}$ anonimnost in molk ter živijo v socialni izolaciji.

Naša naloga bi bila v APŠ samo delno izpolnjena, če bi izpustili ljudi, ki v kraju najbolj potrebujejo znanje. Zato smo si še bolj prizadevali predvsem v zvezi z najmanj izobraženimi. Iskali smo načine, kako bi jih sami odkrili in pridobili za sodelovanje.

Drugi poskus je bil povezan s ponovnim obiskom kraja, kjer bo APŠ potekala. Neposredno smo opazovali različna javna mesta, kjer se srečujejo. Knjižnica je $\mathrm{v}$ tem kraju pomembno vozlišče socialnih stikov, toda tja funkcionalno nepismeni ne prihajajo. Veliko občanov se zbere na občasnih kulturnih prireditvah. Tudi med njimi so funkcionalno nepismeni redki. Ostane nam še kavarna, bifeji, slaščičarne in drugi javni lokali. Tudi tu se srečujejo prebivalci, ki so po izobraženosti nad funkcionalno pismenostjo. Način, da bi navezali stik s funkcionalno nepismenimi lju-

Javno zivlienje ustvarjajo drugi, z boljšth položajev, boli izobraženi, ki so zmožni komunicirati z liıdmi okrog sebe, so sprejemlivi za novosti in tudi sporočajo, kar se jim zdi potrebno. Manj izobraženi pa žvijo neopazno v kraju, v svoj̈ zasebnosti in anonimnosti, zastrti pred javnostjo. Tem se zdi sumlivo, če bi se za njih kdo zanimal. Nihovi socialni stiki so redki in omejeni na zelo ozek krog sorodnikov ali sosede.

dmi na javnih mestih, ni bil pravi, ker ti ljudje tja večinoma ne zahajajo.

Zato smo jih zaman iskali po lokalih, v knjižnici in drugih javnih mestih. Stike z ljudmi v socialno nerazvitem okolju smo dobili šele na kraju samem. Med potekom APŠ so se raziskovalci, udeleženci šole oglasili pri njih doma, ne da bi se prej napovedali.

Čeprav je bila pomanjkljivost prejšnjih priprav prav pridobivanje teh ljudi za sodelovanje, so raziskovalci doživeli zelo topel in iskren sprejem. Nikjer niso bili zavrnjeni. Nasprotno, ljudje so obisk raziskovalcev celo doživljali kot posebno čast in pozornost, ki je sicer niso deležni in ne navajeni. Začudeno so se odzvali, ko so jih raziskovalci spraševali po njihovih problemih, težavah in po tem, kako jih premagujejo, ali morda vidijo sami rešitve. Zdelo se je, kot da jih kaj takega še ni nihče spraševal. Iskreno so pripovedovali o sebi, svojih težavah in razmerah, v katerih živijo. Imeli pa so premalo samozavesti, da bi se že vnaprej strinjali s koordinatorjem, da jih obiščemo na domu. 
Razliko med prvotnim odporom pred sodelovanjem $z$ udeleženci APŠ in načinom, kako so pozneje sprejeli naše raziskovalce, smo si različno razlagali. Manj izobraženi, funkcionalno nepismeni ljudje živijo po svoje in teže sprejemajo dolgoročne cilje. Zato jih je prestrašilo vprašanje, ali bodo poleti sodelovali in sprejeli raziskovalce na pogovor. Večinoma razumejo le kratkoročne cilje, to, kar se neposredno pokaže kot potrebno. Obenem se jim je zdelo nerazumljivo, zakaj bi se nepoznani ljudje sploh zanimali za njihove težave, saj tudi njih same ne zanima, kaj se dogaja nekoliko dlje od domačega praga.

Ko je raziskovalec le potrkal na njihova vrata, ko so bili brez lastnega odločanja pahnjeni $\mathrm{v}$ ta položaj, so razgovor sprejeli kot nekakšno nagrado in lepo doživetje. Raziskovalce so celo pogostili in jih povabili, naj še pridejo. Dogodek so doživeli zadosti prijetno, da so si želeli, da bi se še ponovil.

Kot $\mathrm{v}$ vsakem interakcijskem izobraževanju smo tudi v APŠ naleteli na marsikaj nepredvidljivega, ker ni mogoče uvideti vnaprej, kako se bodo ljudje odzvali, zato smo izobraževalci postavljeni pri tovrstnem izobraževanju pred mnoge neznanke. Pripravljeni moramo biti, da se prilagodimo nastalemu položaju in ne odstopimo, ampak nadaljujemo tudi, ko nas

\section{Bistvo}

interakcijskega izobraževanja je povezava z okoljem. presenetijo povsem drugačni dogodki v primerjavi s tistimi, ki smo jih predvidevali na začetku. Lep primer nepredvidenih odzivov je bilo njihovo odklanjanje, da bi se sestali z udeleženci APŠ. In tudi potem, ko smo jih skušali sami, brez lokalnih koordinatorjev, poiskati, smo jih iskali na napačnih mestih. Spet smo izhajali predvsem iz lastnih meril in načina življenja, premalo pa smo se vživeli v ljudi iz manj razvitega socialnega okolja.

\section{INTERAKCIJSKO IZOBRAŽEVANJE KOT OBLIKA POSEGANJA V NEPOSREDNO OKOLJE}

Interakcijsko izobraževanje se ne konča s samim opazovanjem okolja in raziskovanjem, pogovori in spoznavanjem potreb ter predlogov ljudi. Izobraževalci pripravljajo v drugi fazi interakcijskega izobraževanja konkretne izobraževalne programe in jih skušajo vpeti v neposredno okolje. Tako so v APŠ oblikovali predloge za tri izobraževalne programe za odrasle, po enega za posamezno obravnavano področje: izobraževanje mlajših brezposelnih, izobraževanje starejših in izobraževanje funkcionalno nepismenih.

Nizka stopnja socialne samozavesti in onejena sposobnost za komuniciranje zadržujejo delovanje funkcionalno nepismenih na najnižji preživetveni ravni. Ne poglabljajo se v druge ljudi in šrrše okolje. Ukvarjajo se predvsem sami s seboj in še to jim povzroča precejšnje težave.

V interakcijskem izobraževanju se sodelovanje z okoljem nadaljuje, dokler se dejansko ne začnejo predvideni programi. Izobraževalci morajo to že pred začetkom upoštevati, zato naj se lotijo takih izobraževalnih programov, ki bodo zares uresničljivi in ne bo ostalo samo pri besedah in ugotavljanju potreb. Sodelujoči morajo videti neposredne posledice vseh pogovorov in sodelovanja $\mathrm{z}$ izobraževalci. Brez tega bi jih pustili na pol poti, izobraževanje bi obstalo, še preden se je dejansko začelo.

Temu načelu so bile prilagojene tudi teme, iz katerih so izhajale tri skupine udeležencev $\mathrm{v}$ APŠ. Prizadevanj, da bi izboljšali življenje mlajših odraslih, ki niso dokončali šolanja in so brezposelni, so se lotile že druge občinske službe v občini. V kletnih prostorih knjižnice so uredili prostore za mladinski klub, Center za socialno delo ima izdelan program aktivnosti, ki naj bi odvračal mlade zlasti od mamil in alkoholizma. Še vedno pa mladim primanjkuje znanja, da bi bili sposobni kreniti na življenjsko pot in sprejeti temeljne odločitve za svoje prihodnje življenje.

Prav tako so se tudi v tej občini že prej pojavile želje po univerzi za tretje življenjsko obdobje. Nekaj upokojencev se na študijske krožke vozi celo v sosednjo Gorico. V kraju je tudi nekaj strokovnjakov, ki so pripravljeni postati mentorji. Problemov ne bi bilo niti s prostori. Javna občila so zadosti razvita (lokalni radio, regijska televizija, dnevni tisk, razna lokalna glasila itd.), da bi prevzela vlogo obveščanja in animiranja med starejšimi občani. Tudi v tem primeru smo interakcijsko izobraževanje, tako kot ga zahteva metoda, postavili na stvarna tla in utemeljili na sodelovanju z občani. 


\section{IZOBRAŽEVANJE FUNKCIONALNO NEPISMENIH}

Ajdovščina, kjer poteka APŠ, je izrazito industrijski kraj. Ko smo preučevali izobrazbeno strukturo prebivalstva po popisih iz leta 1981 in 1991, smo ugotovili, da je v kraju zelo malo višje- in visokoizobraženih ljudi. Tudi sloj s srednjo izobrazbo je razmeroma maloštevilen. Industrijsko delo je temeljilo predvsem na priučenih delavcih z nedokončano ali končano osnovno šolo. Izobrazbeno strukturo prebivalstva po zadnjem štetju smo pripravili tudi za druge občine in razdelili gradivo med udeležence.

Leta, ki so jih delavci preživeli predvsem ob fiziènem delu, odločali in vodili pa so drugi ljudje, so povzročala hitro upadanje njhovih intelektualnih in komunikacijskih sposobnosti. Kot povsod drugje je tudi v tem kraju industrija pustila za seboj mnoŽico funkcionalno nepismenih ljudi, ki si danes le $s$ težavo zagotavliajo preživetje. Pri novem načinu dela fizični delavci niso več potrebni, za kaj drugega pa niso sposobni.

Vodilne tovarne v kraju še vedno zaposlujejo precejšnje število ljudi, ker imajo staro tehnologijo. Zato večje brezposelnosti kraj še ne čuti. Zatika pa se pri cenah izdelkov, v pohištve$\mathrm{ni}$ industriji in predelovalni industriji sokov, proizvodnji testenin in tekstilni tovarni. S funkcionalno nepismenimi delavci si tovarne zaman prizadevajo, da bi dvignile kvaliteto svojih izdelkov in znižale ceno. Zaradi zastarele opreme $\mathrm{v}$ proizvodnji, kamor še vedno ekstenzivno zaposlujejo delavce, so njihove cene previsoke in čedalje manj konkurenčne. To, da bi kaka tovarna $\mathrm{v}$ zadnjih petih letih pocenila svoje izdelke, se v kraju še ni zgodilo. $\mathrm{Na}$ osnovi analiz, ki smo jih izdelali v pripravah na APŠ, smo lahko ugotovili, da kljub današnjemu zatišju v kraju, ko brezposelnost še ni tako velika, da bi vnesla pretirano negotovost in socialni nemir, kraju grozi v bližnji prihodnosti razpad industrijske proizvodnje, ki temelji na zastareli tehnologiji, ali pa bo nujna modernizacija opreme in proizvodnega procesa $\mathrm{z}$ uvajanjem računalniško vodene tehnologije. V obeh primerih bo sledilo množično odpuščanje delavcev in funkcionalno nepismeni prebivalci bodo postavljeni pred neobvladljive probleme. Zato smo se še posebno pozorno lotili tega problema. Pri teh programih še niso zagotovljeni pogoji za izvedbeno fazo, kot so pri prvih dveh temah, vendar so potrebe tolikšne, da morajo potekati vnaprejšnje priprave na to, kako se bodo v občini lotili odpravljanja funkcionalne nepismenosti občanov. To pa smo pri načrtovanju APŠ že upoštevali. Vendar za to manjkajo še nekateri objektivni pogoji, kot so razširitev Ljudske univerze in kadrovska krepitev, povečanje andragoške ponudbe in usposobljeni strokovnjaki za sociokulturno animacijo.

$\mathrm{V}$ drugi, izvedbeni fazi se izobraževalci ne obračajo samo na svoje ciljne skupine, ampak sodelujejo tudi s predstavniki javnih občil: lokalnega radia, televizije in časopisov. Udeleženci so pripravili lepake za svoje izobraževalne programe v prihodnosti. Imeli so tudi posebno oddajo na lokalnem radiu in pripravili so sporočilo za tisk. To so rezultati enotedenskega dela, ki dokazujejo, da je učenje uspešno. Hkrati se pogovarjajo o materialni podlagi za izvajanje andragoških programov, kot so izvajalci, finančna sredstva, prostori in drugo. Nastajajoči izobraževalni program skušajo vključiti v konkretne razmere in ga pripeljati do te stopnje, da bi dejansko zaživel, in ga nato prepustiti domačim andragogom.

\section{INTERAKCIJSKO IZOBRAŽEVANJE KOT VAJA ZA DELOVANJE V LASTNI OBČINI}

V interakcijskem izobraževanju udeleženci do skrajnosti upoštevajo konkretne skupine, ljudi, s katerimi so navezali stik in ustvarili razmere $\mathrm{v}$ določenem kraju. Zato je tak način izobraževanja odvisen od dejanskih razmer. Kljub temu mora opraviti svoje poslanstvo in pripraviti ljudi, ki tako izobražujejo, da so sposobni nekaj podobnega ponoviti tudi $\mathrm{v}$ svojem okolju. Programi na APŠ naj bi bili za udeležence vzorčni postopki, čeprav so se na koncu morali oblikovati dejanski izobraževalni programi, Izobraževalni
programi za razvoj
kraja so rezultat
neposredne
interakcije z ljudmi. ki jih bodo imeli v Ajdovščini v prihodnosti na voljo. Novi programi v vseh treh skupinah so nastajali za vajo, vendar na osnovi neposredne interakcije, pogovorov, opazovanja in poslušanja resničnih usod ljudi v kraju. Tudi
As 20y 
vaja je bila nekaj, kar v interakcijskem izobraževanju ni samo vaja, ampak nekaj dejanskega.

Prenos znanja, ki si ga udeleženci APŠ pridobijo pri enotedenskem skupnem učenju, v domače razmere poteka po analogiji. Udeleženci $\mathrm{v}$ svoji skupini intenzivno sodelujejo. Skupine so štele do 14 ljudi in vsaka skupina je imela svojega mentorja. Po potrebi so se razdelile še na manjše skupine in takrat so bile interakcije med udeleženci APŠ očitno še veliko intenzivnejše. Čim bolj se je stopnjevala interakcija, tem bolj se je oblikovala skupina, ki se je znašla v poletni šoli kot posebna socialna skupnost. Proti koncu šole so vodilne na to opozarjale zlasti izjave, da bi ustanovili poseben klub udeležencev APŠ ali pa bi uvedli kako drugo obliko, v kateri bi se medsebojno druženje nadaljevalo tudi pozneje, med letom, in da se ne bi srečevali le na poletni šoli. Precejšen del skupine so sestavljali tudi udeleženci iz prejšnje APŠ.

Ker smo želeli, da bi bila interakcija čim intenzivnejša tudi med predavatelji in udeleženci, smo omejili tudi v plenarnem delu število udeležencev na 35 do 40 ljudi. Poleg plenarnega dela, ki je potekal v dopoldanskem času, so se udeleženci APŠ in predavatelji družili med seboj tudi v kulturnem programu ob večerih in neformalno med kosilom, ob kavi in drugih priložnostih. Precej pozornosti je bilo namenjene temu, da so bili čim več skupaj in da so bili odnosi čim bolj sproščeni.

Posameznim predavateljem je vodstvo APŠ priporočalo, naj z udeleženci preživijo ves teden. Temu vabilu so se ljubeznivo odzvali tudi tuji predavatelji in so kljub časovni stiski ostali med nami dlje časa. Očitno jih je pritegnilo razpoloženje APŠ in iskrena prizadevanja, da bi se skupaj čim več naučili in odkrili čim več skupnega.

\section{SKLEPNE MISLI}

APŠ razvija nove oblike izpopolnjevanja in izobraževanja. Način nastajanja, organizacijo, izvedbene oblike in interakcijsko izobraževanje smo nekoliko podrobneje opisali, da bi bralce seznanili z novostmi in spodbudili čim več strokovnjakov za tak način izobraževanja. celotno dogajanje. Po dosedanjih evalvacijah se je udeležencem najgloblje vtisnilo popoldansko delo na terenu. Predavanja jemljejo sicer kot sama po sebi umevna, $v$ večernem kulturnem delu pa se občutek, da so se prišli učiti, porazgubi. Izobraževanje se pomeša z zabavo in postane zelo neformalno. Učijo se, ne da bi se tega posebej zavedali.

Pomembno vlogo v APŠ prevzame tudi organizatorka, ki povezuje dogodke zunaj predavalnice, skrbi za udeležence med odmori in daje posebno noto celotnemu seminarju. Čeprav sledi predavanjem, skrbi za vsakega udeleženca posebej in skuša izpolniti želje posameznih udeležencev. Na lastno pobudo predlaga še nove stvari, ki jh vodstvo APŠ ni vnaprej predvidelo. Rešuje tudi zadrege, ki nastanejo zaradi sprememb programa in se skuša temu prilagoditi.

Interakcijsko izobraževanje zahteva od sodelujočih precejšnjo prilagodljivost in pripravljenost na spremembe in odkrivanje novega. Zadovolji željo po raziskovanju in lastni aktivnosti ter odločanju, ki jo andragogi prinesejo s seboj na poletno šolo. Vodijo in so hkrati vodeni. Poslušajo in pripovedujejo, posnemajo in morajo biti izvirni. Med seboj se prepletajo različne izobraževalne metode. Predvsem pa so metode prilagojene skupnostnemu izobraževanju, pospeševanju razvoja ljudi in okolja.

\section{LITERATURA}

Adult Education and Comunity Development, Council of Europe, Strasbourg, 1987.

Jennings, B.: Comunity Colleges in England and Wales, NIAE, Leicester, 1990.

Plesser-Loper C., Rohlmann R.: Die Rolle Der Kommunal orientierten Erwachssenenbildungorganisationen In Europa, DVV Institut für internationale Zusammenarbeit, Bonn, 1994.

Socio-cultural Work in Flanders, European Bureau of Adult Education, Mechelen, 1993.

Creating Citizens through the Public Deliberation, Kettering Foundation, Ohio, Dayton, 1994.

Krajnc, A.: Izobrazbena struktura prebivalstva Slovenije, Filozofska fakulteta, Ljubljana, 1993.

ANDRAGOGIJA, Školska knjiga, Zagreb, 1992.

Na koncu vsake APŠ udeleženci ovrednotijo 